\title{
Financial Derivatives and Bank Risk: Evidence from D-8 Countries
}

\section{Finansal Türevler ve Banka Riski: D-8 Ülkeleri Örneği}

\section{Zekeriya GÜL ${ }^{1}$, Şükriye Gül REİS ${ }^{2}$}

\begin{tabular}{|c|c|}
\hline Abstract & Öz \\
\hline $\begin{array}{l}\text { Purpose: The study aims to investigate the impact of financial } \\
\text { derivatives use on bank risk. For this purpose, the banks operating in } \\
\text { D- } 8 \text { countries, are investigated. }\end{array}$ & $\begin{array}{l}\text { Amaç: Bu çalışmanın amacı, finansal türev kullanımının banka riski } \\
\text { üzerindeki etkisini araştırmaktır. Bu amaçla D-8 ülkelerinde faaliyet } \\
\text { gösteren bankalar incelenmiştir. }\end{array}$ \\
\hline $\begin{array}{l}\text { Design/Methodology: While the relationship between the bank risk } \\
\text { and derivative utilize is examined, some of the bank-specific control } \\
\text { variables are added to the model. Due to the sample structure and } \\
\text { endogeneity problem in the study, hypotheses were tested again by } \\
\text { using Generalized Moments Method. }\end{array}$ & $\begin{array}{l}\text { Tasarım/Yöntem: Banka riski ile türev kullanımı arasındaki ilişki } \\
\text { incelenirken bankaya özgü bazı kontrol değişkenler modele } \\
\text { eklenmiştir. Çalışmada örneklem yapısı ve içsellik probleminin } \\
\text { önüne geçmek için, Genelleştirilmiş Momentler Yöntemi } \\
\text { kullanılarak hipotezler yeniden test edilmiştir. }\end{array}$ \\
\hline $\begin{array}{l}\text { Findings: The analysis results showed a statistically significant and } \\
\text { negative relationship between financial derivative use and bank risk } \\
\text { and using financial derivatives is reduced the bank's risk. } \\
\text { Limitations: From D- } 8 \text { countries, Iran and Bangladesh were } \\
\text { excluded from the study because of the inaccessibility of the data } \\
\text { related to the financial derivatives. }\end{array}$ & $\begin{array}{l}\text { Bulgular: Analizlerin sonucu; finansal türev araçlarının kullanımı } \\
\text { ile bankacıllk riski arasında negatif ve istatistiksel olarak anlamlı bir } \\
\text { ilişki olduğunu ve finansal türev kullanımının bankaların riskini } \\
\text { azalttığını göstermektedir. } \\
\text { Sinırlılıklar: D-8 ülkelerinden İran ve Bangladeş'in finansal türev } \\
\text { ürünlerine ilişkin verilerine erişilememesi nedeniyle İran ve } \\
\text { Banglades örneklem dışında bırakılmıştır. }\end{array}$ \\
\hline $\begin{array}{l}\text { Originality/Value: While the relationship between "Banking Risk } \\
\text { and Use of Derivative Financial Instruments" in the literature is } \\
\text { mainly tested in developed countries, there is a gap in the literature } \\
\text { on how this relationship is in developing countries. This study aims } \\
\text { to contribute to the literature by revealing the relationship between } \\
\text { the use of financial derivatives and bank risk in D-8 countries, which } \\
\text { are classified as developing countries. } \\
\text { Keywords: Financial Derivatives, Bank Risk, D-8 Countries, Z- } \\
\text { Score, Emerging Countries }\end{array}$ & $\begin{array}{l}\text { Özgünlük/Değer: Literatürde "Bankacılık Riski ile Türev Finansal } \\
\text { Araçların Kullanımı" arasındaki ilişki ağırlıklı olarak gelişmiş } \\
\text { ülkelerde test edilirken gelişmekte olan ülkelerde bu ilişkinin nasıl } \\
\text { olduğu konusunda literatürde boşluk bulunmaktadır. Bu çalışmanın, } \\
\text { gelişmekte olan ülkeler olarak sınıflandırılan D-8 ülkelerinde } \\
\text { finansal türev kullanımı ile banka riski arasındaki ilişkiyi ortaya } \\
\text { koyarak literatüre katkı sağlaması amaçlanmaktadır. } \\
\text { Anahtar Kelimeler: Finansal Türevler, Banka Riski, D-8 Ülkeleri, } \\
\text { Z-Skoru, Gelişmekte Olan Ülkeler }\end{array}$ \\
\hline
\end{tabular}

1 PhD Student, Gaziantep University, Graduate School of Social Sciences, Department of Business Administration, zekeriyagu188@gmail.com, ORCID: 0000-0002-4241-117X

${ }^{2}$ Assist. Prof. Dr., Gaziantep University, Faculty of Economics and Administrative Sciences, Department of Business Administration, greis@gantep.edu.tr, ORCID: 0000-0001-7654-4256 


\section{INTRODUCTION}

The financial risks that firms and banks are exposed to have increased because of the growth of transaction volumes, intensification of the competitive environment, expansion, and spread of the activities of these businesses to include the international market. Nowadays, banks are not only affected by the economic developments in the country where they were established, but also by the crises, fluctuations, and uncertainties that arise in the world economy. This situation contributed to the banks managing the risks in a more sensitive and careful approach. The banks try to eliminate or reduce the risks, to sustain their economic lives and to avoid any financial problems that may encounter them in the future. For these reasons, various hedging strategies have been developed over time. In recent years, the most effective tools used for hedging are derivative products (Y1lmaz \& Aslan, 2016).

International big companies and banks use derivatives products generally for hedging risks. The fluctuation in the risk exposures, such as commodity prices, interest rates and foreign currency which are classified as underlying assets, cause problems for businesses. Increases in prices create an atmosphere of uncertainty in the market, disrupting the cash flows of businesses and banks. This causes an unexpected search for financing and causes extra costs. Derivative products are used to minimize these risks and can be traded in both organized and over the counter markets. The main financial derivatives are forward, futures, option, and swap.

Financial derivatives can be extremely useful in risk management. However, when banks misuse derivatives, it can create additional risks that can lead the economy into a financial crisis (Adcock et al., 2014). Derivatives have caused the collapse or bankruptcy of successful companies and banks in the global financial markets over the past two decades. Financial derivatives had a major impact on the collapse of barings bank in 1995, Enron in 2001 and Lehman brothers in 2008 (McDonald, 2013). Although the derivatives activities of banks became increasingly controversial after the global financial crisis in 2008, their popularity did not change much when looking at transaction volumes (Chang et al., 2018).

Financial derivatives are financial instruments whose value fluctuates in response to changes in the price of an underlying asset such as; foreign currency exchange rates, interest rate, commodity, security price, or index (Morgan, 2013). Financial derivatives provide an efficient mechanism that is conducive to the risk-sharing of the underlying assets traded in the derivatives market and helps producers cope with price fluctuations. Moreover, financial derivatives play a significant role in managing the risk by increasing capital cash flows in developing and developed countries (Vo et al., 2019). Derivatives markets attract an increasing number of participants due to their high liquidity. Any participant can easily find a counterparty for the transaction (Shen \& Hartarska, 2013).

Following the collapse of the Bretton Woods system in 1973, as well as fluctuations in interest and exchange rates on the currency markets, banks have been exposed to high foreign exchange and interest rate risks. As a result of these developments, derivative instruments, which were previously only used for agricultural products, started to be used for interest and foreign exchange underlying assets. (Y1lmaz \& Aslan, 2016: 664).

The basic features of financial derivatives can be summarized as follows (Kasilingam, 1997):

- Financial derivatives are a future contract between two parties.

- The value of derivatives related to the value of the underlying asset and depends on the changes in the value of underlying asset, thus it can sometimes be zero.

- The liabilities of the parties differ according to the type of derivative instrument.

- Physical delivery is not made for many of the underlying assets subject to financial derivatives. Therefore, there is no limit on the number of positions taken.

The traditional role of the banks is to act as intermediaries for fund transfers to their customers. For performing these services, banks take certain risks and work on managing these risks. Risk management and risk sharing are considered as fundamental value creation in the banking sector 
due to technological, information and financial innovations. The use of derivatives in the world and in USA banks was very low in 1991 because only large institutions had the necessary resources for using effectively derivatives products (Gunther \& Siems, 1995). While banks' derivatives activities became more controversial following the global financial crisis in 2008, their popularity did not change significantly when transaction volumes were considered. (Chang et al., 2018).

There are two main reasons for a bank to use derivatives. The first reason is to reduce (hedging) or avoid the risk, whereas the second is speculation that aims to gain profit from expected market movements (Sundaram \& Das, 2011). In the study, the use of total derivatives was taken into consideration because the data of derivatives for hedging and speculation could not be accessed separately. The impact of derivative usage on banking risk has been investigated in this study because the banking sector is the most important pillar of the financial system and the importance of using derivative products in the banking sector. Moreover, as the relationship between bank risk and derivatives usage has not been sufficiently investigated in developing countries in the literature, thus this article contributes to the existing literature by providing evidence on the effect of derivatives usage on banks risk in developing countries. For this purpose, panel data regression analysis was used to analyze the data for banks operating in D-8 countries. For this purpose, panel data regression analysis was used to analyze the data for banks operating in D-8 countries. The results obtained show that banks reduce their risks by using derivatives within the scope of the sample used.

\section{LITERATURE REVIEW}

In the literature, there are studies that mainly analyzed the effects of derivative use on performance. Apart from these, it has been observed that the researches on bank risk and derivatives use are mainly tested in developed countries whereas this relation has not been investigated or examined in developing countries. Based on this gap in the literature, this study investigates the impact of derivative use on non-systematic risk in banks in developing countries. The studies in the literature are summarized below:

Rivas et al. (2006) analyzed the effect of financial derivatives usage on the efficiency of the bank by conducting a study on 182 banks operating in Brazil, Chile, and Mexico. Data envelopment analysis (RIA) was used in the study. The results showed that usage of financial derivatives has increased the efficiency of the banks and as the banks' size gets bigger their efficiency levels are increased. Furthermore, it was found that structural and regulatory restrictions have a negative impact on the efficiency of Latin American banks.

Mallikarjunappa and Afsal (2008) analyzed the effects of the usage of derivatives on the volatility of the stock market in India through the use of S\&P and CNX Nifty Indexes between October 1995 and June 2006. GARCH model was used by including dummy variables for option and future derivatives in the conditional variance equation. The results showed persistence of volatility before and after the usage of derivatives. The index return to market return sensitivity, as well as any day of the week impact, has vanished in the post derivatives era.

$\mathrm{Li}$ and $\mathrm{Yu}(2010)$ analyzed the effect of using derivatives on 18 major commercial banks in the United States by using the random and fixed effects models from panel data analysis. It has been observed that usage of derivatives raises the risk level of large banks and the large banks take more speculative positions in derivative contracts as strategic for risk management, whereas small banks prefer to make derivative transactions to avoid the risks. According to the results, even though the large banks increase their profitability with speculative derivative transactions, but also they increase their risks in general by doing derivatives transactions.

Shen and Hartarska (2013) studied the effect of using derivatives on the profitability of derivatives users and non-user agricultural banks. The data from 2006, 2008, and 2010 with over 2,000 observations that were used in the analysis were taken from the Federal Reserve Bank of Chicago. The findings revealed that the management of agricultural banks risk by using derivatives is efficient and the profitability of agricultural banks which use derivatives is less influenced by credit and interest risk during the study period. 
Ahmed et al. (2014) analyzed the financial derivatives hedging effect on the value and financial performance of the firms. The research was conducted during the time 2005-2012 on 288 non-financial companies listed on the FTSE-All Index on the London Stock Exchange (LSE). The findings show that risk management effectiveness differs greatly depending on the financial risks and derivatives used for hedging, and the interest rate risk hedging and performance of firm have a negative relationship with overall hedging but a positive relationship for hedging with forwarding contracts. Additionally, The results indicate that the financial crisis of 2008-2009 had no substantial impact on the firm's existing risk management activities or exposure to financial risk hedging with derivatives.

Lenee and Oki (2016) investigated the impact of the usage of derivatives on hedging the risk of interest rates and foreign exchange rates between 2005-2014 for 5 financial and 5 non-financial companies chosen from the UK FTSE 100 index. The results concluded that financial firms use a forwards and futures derivatives combination to hedge interest rate risks, while non-financial firms use a futures and forwards derivatives combination to hedge interest and foreign exchange rates risks. Moreover, It is found that the return on assets has a statistically significant and positive relationship with the use of the combination of forwarding and futures derivatives.

Ghosh (2017), examined derivatives use effect on bank risks and profitability by using data between the 2001 second quarter and the 2016 first quarter for 5491 commercial banks operating in the United States. The fixed effects and Bayesian models averaging techniques from panel data were used in the study. The finding concluded that derivatives of interest and exchange rate, as well as their various constituent types, have reduced the insolvency risks of the banks over the whole period span and before the crisis.

Chang et al. (2018) investigated the impact of the usage of derivatives on the risk and market value of the banks by analyzing commercial banks operating in 30 European countries between 2004 and 2008. The findings indicated that the profitability of the banks has a significant and positive relationship with the usage of interest rate and foreign exchange derivatives, and foreign exchange derivatives are more likely to be used by banks that have high deposits and liquidity value. Moreover, the bank risk increases by using the interest rate and the foreign exchange derivatives.

\section{DATA AND METHODOLOGY}

47 banks operating in D-8 countries throughout 2011 to 2018 were included in the study to examine the financial derivatives use effect on banks' risks. These countries are Turkey, Malaysia, Egypt, Indonesia, Nigeria, and Pakistan. Iran and Bangladesh were excluded from the study because of the unavailability of the data during the period included in the study. Additionally, the reason behind including only the period between 2011-2018 in the analysis is the inaccessibility of data for more recent years. The primary sample of the study consists of 250 banks operating in D-8 countries which are included in the study. The number of banks which use the financial derivative is from 250 to 174 banks. However, the number of the banks which have eight years of data on derivative size for the period 2011-2018 is just 47 Bank. Most of the 47 banks included in the study are the biggest banks in terms of the size of assets. For Indonesia and Nigeria, the first-ranked banks in terms of asset volume were not included in the research due to the inaccessibility of financial derivative data for these banks during the study period. Moreover, the reason for including the mid-ranked banks regarding asset size and having financial derivatives data for the included period is to get better realistic results by increasing the size of the sample. The balance sheets and income statements of the banks included in the studies were analyzed. Table 1 shows the banks by country, total assets of each bank in 2018 (Start Credits, 2018; The Banks Association of Turkey, 2018; KPMG Banking Survey, 2018; Indonesia Investment, 2018; Global from Asia, 2018; Hapijournal, 2018) and the ranking of the banks which were used in the analysis by the total asset. 
Table 1: Banks Used in the Analysis by Country and Total Asset by the Year 2018

\begin{tabular}{|c|c|c|c|c|c|c|c|}
\hline & Indonesia & $\begin{array}{l}\text { Total Asset } \\
\text { (USD Dollar) }\end{array}$ & Ranking & 25 & MCB Bank Limited & $1,585.2100$ & 4 \\
\hline 1 & Bank Mandiri & $83,022,726$ & 2 & 26 & Silkbank Limited & 173,677 & 20 \\
\hline 2 & $\begin{array}{l}\text { Bank Central } \\
\text { Asia }\end{array}$ & $56,956,560$ & 3 & 27 & Citibank NA Pakistan & 140,948 & 21 \\
\hline 3 & Bank Negara & $55,836,752$ & 4 & & Nigeria & $\begin{array}{c}\text { Total Asset } \\
\text { (Nigeria Naira) }\end{array}$ & Ranking \\
\hline 4 & Bank CIMB & $18,422,864$ & 6 & 28 & First Bank Nigeria & $5,242,372$ & 2 \\
\hline 5 & Bank Panin & $14,308,709$ & 7 & 29 & Access Bank & $3,968,114$ & 3 \\
\hline 6 & Bank Danamon & $12,897,051$ & 8 & & Turkey & $\begin{array}{c}\text { Total Asset } \\
\text { (Turkish Lira) }\end{array}$ & Ranking \\
\hline 7 & Bank Maybank & $12,259,710$ & 9 & 30 & T.C. Ziraat Bankası & $537,156.13$ & 1 \\
\hline 8 & $\begin{array}{l}\text { Bank OCBC } \\
\text { NISP }\end{array}$ & $11,986,941$ & 10 & 31 & Türkiye is Bankası & $416,387.60$ & 2 \\
\hline 9 & Bank Tokyo & $11,770,546$ & 11 & 32 & $\begin{array}{l}\text { Türkiye Garanti } \\
\text { Bankası }\end{array}$ & $359,477.20$ & 4 \\
\hline 10 & Bank Permata & $10,558,170$ & 12 & 33 & Türkiye Halk Bankası & $378,422.06$ & 3 \\
\hline 11 & Bank Hsbc & $7,524,408$ & 15 & 34 & $\begin{array}{l}\text { Yap1 ve Kredi } \\
\text { Bankas1 }\end{array}$ & $348,043.59$ & 5 \\
\hline 12 & Bank UOB & $7,159,447$ & 16 & 35 & Akbank & $327,642.13$ & 7 \\
\hline 13 & Bank CTBC & $4,136,345$ & 26 & 36 & $\begin{array}{l}\text { Türkiye Vakıflar } \\
\text { Bankası }\end{array}$ & $331,355.64$ & 6 \\
\hline & Malaysia & $\begin{array}{c}\text { Total Assets } \\
\text { (Malaysian } \\
\text { Ringgit) }\end{array}$ & Ranking & 37 & Denizbank & $137,657.95$ & 10 \\
\hline 14 & Malayan Banking & 765.300 & 1 & 38 & $\begin{array}{l}\text { Türk Ekonomi } \\
\text { Bankası }\end{array}$ & $96,997.16$ & 11 \\
\hline 15 & CIMB Bank & 514.482 & 2 & 39 & Şeker Bank & $31,321.32$ & 17 \\
\hline 16 & Public Bank & 407.575 & 3 & 40 & HSBC Bank & $32,811.34$ & 14 \\
\hline 17 & RHB Bank & 234.464 & 4 & & Egypt & $\begin{array}{c}\text { Total Asset } \\
\text { (USD Dollar) }\end{array}$ & Ranking \\
\hline 18 & Maybank & 210,536 & 6 & 41 & National Bank & $86,549.943$ & 1 \\
\hline 19 & $\begin{array}{l}\text { Hong Leong } \\
\text { Bank }\end{array}$ & 202.890 & 7 & 42 & $\begin{array}{l}\text { Commercial Inter } \\
\text { Bank }\end{array}$ & $19,164.780$ & 2 \\
\hline 20 & $\begin{array}{l}\text { United Overseas } \\
\text { Bank }\end{array}$ & 388,099 & 5 & 43 & African Export-Import & $13,419.370$ & 4 \\
\hline 21 & $\begin{array}{l}\text { HSBC Bank } \\
\text { Malaysia }\end{array}$ & 79.494 & 10 & 44 & Bank Audi SAE & $3,827.845$ & 11 \\
\hline \multirow[t]{2}{*}{22} & Affin Bank & 71.985 & 11 & 45 & Emirates National & $3,203.881$ & 15 \\
\hline & Pakistan & $\begin{array}{c}\text { Total Asset } \\
\text { (Rupees) }\end{array}$ & Ranking & 46 & Credit Agricole Bank & $2,997.263$ & 17 \\
\hline 23 & Habib Bank & $3,025.853$ & 1 & 47 & Attijariwafa Bank & $1,777.485$ & 25 \\
\hline 24 & United Bank & $2,002.493$ & 3 & & & & \\
\hline
\end{tabular}

\subsection{Data Used in the Study}

The data used in the research were obtained from the Bankscope database. The ratios which were used in the study were calculated from the data obtained through the balance sheet and income statements. The ratios used in the study are shown in Table 2.

Table 2: The Variables of the Study

\begin{tabular}{lll}
\hline Variables & Code & Data Sources \\
\hline Dependent Variable & & \\
\hline Z-Score (Bank Risk) & ZS & Bank Scope \\
\hline Independent Variables & DS & Bank Scope \\
\hline Derivative Size = Log (Derivative Assest + Derivative Liabilities) & BS & Bank Scope \\
\hline Bank's Size = Log (Assets) & DA & Bank Scope \\
\hline Deposits / Assets & LA & Bank Scope \\
\hline Loans / Assets & LD & Bank Scope \\
\hline Loans / Deposits & ROE & Bank Scope \\
\hline Return on Equity = Net Income / Shareholders' Equity & Tier1 & Bank Scope \\
\hline Tier1 (Capital Adequacy Ratio) & LTA & Bank Scope \\
\hline Total Liquidity Assets / Total Assets & & \\
\hline
\end{tabular}




\subsection{Research Method and Empirical Model}

Generalized Method of Moments (GMM) is a technique that is used in first-order autoregressive processes with a high number of cross-section data and a small-time dimension (Bowsher, 2002). The econometric model is expected to have a dynamic structure since the model subject to prediction in the study is considered to be a dynamic model. Dynamic panel data models, unlike static panel data models, are models that contain delayed variables or variables. There are two types of dynamic panel data models: distributed delayed panel data models and autoregressive panel data models. Although the lagged values of the dependent variable are defined as independent variables in autoregressive panel data models, the delayed values of the independent variables are considered as independent variables in distributed delayed panel data models. In distributed delayed panel data models, the problem of multiple linear dependence between the delayed values of the independent variable is frequently encountered. Generally, when it comes to dynamic models, autoregressive models come to mind first (Baykut et al., 2019) The validity of estimation results of the GMM test can be checked by using Sargan and autocorrelation test (İskenderoğlu, 2008). The Sargan test checks the validity of the predictions is tested with instrument variables and whether the instrument variables fully reflect the main variables is measured (Gujarati, 2004). Whereas, the AR1 and AR2 autocorrelation tests are used to test whether there are specification and autocorrelation problems in the dynamic panel data estimation model results in GMM models (Arellano \& Bond, 1991).

The System GMM model, which is used to check the impact of use of financial derivatives on bank risk and estimated using the following model:

$$
\begin{aligned}
& Z S_{l t}=a_{0}+a_{1} Z S_{i, t-1}+a_{2} D S_{i, t}+a_{3} B S_{i, t}+a_{4} D A_{i, t}+a_{5} L A_{i, t}+a_{6} L D_{i, t}+a_{7} R O E_{i, t}+ \\
& a_{8} \text { Tier }_{i, t}+a_{9} L T A_{i, t}+u_{i t}
\end{aligned}
$$

The below formula was used to calculate the bank risk, namely Z-Score:

$$
=\left[(R O A)_{i, t}+\left(\frac{\text { Total Equity Capital }_{i t}}{\text { Assets }}\right)_{i, t}\right] / \sigma(R O A)_{i, t}
$$

The main independent variable of the study is the derivative size (SZ), which represents the size of derivative transactions performed by banks. Due to data constraints, it has not been possible to distinguish the different types of derivatives. The dependent variable is the risk of the bank (Z-score). The other independent variables are bank risk over the time t-1, bank size, deposits/assets, loans/assets, loans/deposits, returns on equity, Tier1 (Capital Adequacy Ratio) and total liquidity assets/assets. Independent variables that have been used in the study are the most used variables in the literature.

\section{ANALYSIS AND FINDINGS}

To test the impact of derivatives use on bank risk, some tests were used. First of all to see the structure of variables, calculated descriptive statistics. And then correlation analysis was done and the relationship between variables was put forward. After that unit root tests were used if the variables are stationary or not. Lastly model was estimated by system GMM analysis. The results are reported below, respectively.

\subsection{Descriptive Statistics}

The variables descriptive statistics are important to see the structure of the data. The descriptive statistics results are shown in Table 3. 
Table 3: Descriptive Statistics

\begin{tabular}{lcccccc}
\hline Variables & Observations & Mean & Median & Standard Deviation & Min & Max \\
\hline ZS & 376 & 11.073 & 10.665 & 3.5818 & 3.1785 & 27.911 \\
\hline DS & 376 & 4.8248 & 4.8820 & 1.0829 & 1.3168 & 6.8279 \\
\hline BS & 376 & 7.2534 & 7.2570 & 0.5821 & 5.7533 & 8.2900 \\
\hline DA & 376 & 0.6777 & 0.7004 & 0.1381 & 0.0496 & 0.8891 \\
\hline LA & 376 & 0.5840 & 0.6306 & 0.1447 & 0.1911 & 0.8654 \\
\hline LD & 376 & 1.0277 & 0.9012 & 1.2395 & 0.2839 & 15.862 \\
\hline ROE & 376 & 0.1347 & 0.1349 & 0.0809 & -0.3360 & 0.6271 \\
\hline Tier1 & 376 & 14.794 & 13.230 & 7.2271 & 4.5000 & 83.610 \\
\hline LTA & 376 & 0.1669 & 0.1334 & 0.1058 & 0.0362 & 0.5417 \\
\hline
\end{tabular}

Among the variables of the banks, it can be seen that the standard deviation of the capital adequacy ratio (Tier 1) is the highest, this may arise from the different financing policies, sizes and ownership structures of banks operating in the sector. Another variable with a high standard deviation is bank risk (ZS), the reason behind this is that the banks included in the study operate in different countries.

The correlation coefficient is a mathematical indicator of how strong a relationship exists between certain variables' relative movements. The correlation coefficient takes a value between +1 and -1 . In the case of a high positive or negative correlation coefficient, namely close to +1 or -1 , a multiple linear correlation problem may arise and this may have negative results on the variables related in the analysis (Field, 2009). All the variables have an acceptable level of correlation coefficient values as shown in Table 4.

Table 4: Correlation Matrix

\begin{tabular}{|c|c|c|c|c|c|c|c|c|c|}
\hline Variables & $\mathbf{Z S}$ & DS & BS & DA & LA & LD & ROE & Tier1 & LTA \\
\hline ZS & 1.0000 & & & & & & & & \\
\hline DS & -0.1768 & 1.0000 & & & & & & & \\
\hline BS & -0.2223 & 0.6513 & 1.0000 & & & & & & \\
\hline DA & -0.2655 & -0.4175 & -0.1334 & 1.0000 & & & & & \\
\hline LA & 0.0673 & 0.2977 & 0.2814 & -0.3730 & 1.0000 & & & & \\
\hline LD & 0.1818 & 0.1850 & -0.0231 & -0.2585 & 0.3675 & 1.0000 & & & \\
\hline ROE & 0.1090 & -0.0496 & 0.0721 & 0.0969 & -0.3461 & -0.0687 & 1.0000 & & \\
\hline Tier1 & 0.4165 & -0.1028 & -0.2455 & -0.3077 & -0.0523 & 0.1724 & 0.2001 & 1.0000 & \\
\hline LTA & -0.1602 & -0.2205 & -0.1549 & 0.2290 & -0.2181 & -0.1525 & 0.3350 & -0.0294 & 1.0000 \\
\hline
\end{tabular}

\subsection{Unit Root Test}

To perform panel data analysis and to obtain accurate results, it is essential to ensure the stationarity of time series for variables. In other words, the series must be stationary to provide meaningful results between dependent and independent variables (Topaloğlu, 2018). Table 5 shows the unit root test analysis results.

\section{$\mathrm{H}_{0}$ : Unit Root \\ $\mathrm{H}_{1}$ : No Unit Root}

As the units in the data set consist of different countries, it is essential to take into consideration the heterogeneity. For this reason, two different unit root tests were used, by taking into consideration both homogeneity and heterogeneity. The reason for using the Levin, Lin and Chu (2002) (LLC) test is that it is based on its simplicity and homogeneity assumption. Whereas, the reason for using the Im, Pesaran and Shin (2003) (IPS) test is that it is based on the assumption of heterogeneity. The IPS test was used by economics researchers to analyze long-term relationships in panel data, as it was found to have superior testing power (Afonso \& Rault, 2010). 
Table 5: Unit Root Test Results

\begin{tabular}{lcccccccc}
\hline \multirow{2}{*}{ Variables } & \multicolumn{9}{c}{ LLC Test } & \multicolumn{3}{c}{ IPS Test } \\
\cline { 2 - 9 } & \multicolumn{2}{c}{ Intercept } & \multicolumn{2}{c}{ Intercept + Trend } & \multicolumn{2}{c}{ Intercept } & \multicolumn{2}{c}{ Intercept + Trend } \\
\cline { 2 - 9 } & Stat. & Prob. & Stat. & Prob. & Stat. & Prob. & Stat. & Prob. \\
\hline ZS & -4.17421 & $0.0000^{* * *}$ & -31.8758 & $0.0000^{* * *}$ & -3.54142 & $0.0002^{* * *}$ & -0.70595 & $0.0000^{* * *}$ \\
\hline DS & -11.0891 & $0.0000^{* * *}$ & -49.4359 & $0.0000^{* * *}$ & -2.39336 & $0.0083^{* * *}$ & -3.20816 & $0.0007 * * *$ \\
\hline BS & -4.38100 & $0.0000^{* * *}$ & -26.1241 & $0.0000^{* * *}$ & -2.43239 & $0.0075^{* * *}$ & -0.38042 & $0.0000^{* * *}$ \\
\hline DA & -5.58570 & $0.0000^{* * *}$ & -23.8211 & $0.0000^{* * *}$ & -4.23449 & $0.0000^{* * *}$ & -1.19808 & $0.0000^{* * *}$ \\
\hline LA & -26.1110 & $0.0000^{* * *}$ & -54.0152 & $0.0000^{* * *}$ & -7.93778 & $0.0000^{* * *}$ & -0.86137 & $0.0000^{* * *}$ \\
\hline LD & -11.9261 & $0.0000^{* * *}$ & -4.37258 & $0.0000^{* * *}$ & -0.97018 & $0.0059^{* * *}$ & -1.30942 & $0.0000^{* * *}$ \\
\hline ROE & -8.21051 & $0.0000^{* * *}$ & -10.4471 & $0.0000^{* * *}$ & -2.22760 & $0.0013^{* * *}$ & -0.34171 & $0.0000^{* * *}$ \\
\hline Tier1 & -7.82373 & $0.0000^{* * *}$ & -20.8883 & $0.0000^{* * *}$ & -3.20139 & $0.0007^{* * *}$ & -0.62334 & $0.0009^{* * *}$ \\
\hline LTA & -6.35624 & $0.0000^{* * *}$ & -12.8506 & $0.0000^{* * *}$ & -2.93010 & $0.0017 * * *$ & -0.42000 & $0.0066^{* * *}$ \\
\hline *** denotes significance at the level 1\% & & & & & & &
\end{tabular}

The variables are stationary according to all tests of unit root which shown in Table 5. The $\mathrm{H}_{0}$ hypothesis is rejected because the probability value is lower than all significance values. These results of the unit root test meet the assumption of the GMM test which assume that the variables should be stationary. Therefore, the GMM test is estimated in the following stage.

\subsection{Empirical Findings}

In the system GMM regression model, while analyzing the influence of the independent variable on the dependent variable, the lagged value of the dependent variable is also included in the regression equation as $\left(Z S_{i, t-1}\right)$. The GMM test results for the relationship between financial derivatives use and bank risk is shown in Table 6 .

Table 6: The Results of System GMM Test

\begin{tabular}{lcc}
\hline Dependent Variable: Bank Risk (Z-Score) & Prob. \\
\hline Independent Variables & Coefficient & $0.0668^{*}$ \\
\hline ZS(-1) & -0.109 & $0.0000^{* * *}$ \\
\hline DS & -0.026 & $0.0000^{* * *}$ \\
\hline BS & -0.138 & $0.0003 * * *$ \\
\hline DA & -0.191 & 0.3049 \\
\hline LA & -0.053 & 0.5577 \\
\hline LD & 0.0006 & $0.0009 * * *$ \\
\hline ROE & 0.224 & $0.0000^{* * *}$ \\
\hline Tier1 & 0.004 & $0.0000^{* * *}$ \\
\hline LTA & -0.201 & $0.0037 * * *$ \\
\hline Diagnostic Tests & & 0.2459 \\
\hline Wald test (p-value) & 8.574 & $0.0000^{* * *}$ \\
\hline Sargan Test & 23.918 & 0.2927 \\
\hline AR(1) Probability Value & 3.983 & \\
\hline AR(2) Probability Value & 1.052 & \\
\hline$* * *, * *, *$ denotes significance at the level $1 \%, 5 \%, 10 \%$, respectively & & \\
\hline
\end{tabular}

The results of the Wald test in Table 6, showing that the explanatory variables together are significant in explaining the dependent variable. Furthermore, the Sargan test states that the instrument variables do not have an endogeneity problem (they are external), so the instrument variables are valid according to Sargan test. P-value of the AR(2) test is bigger than $10 \%$ and this result shows there is no second-order serial correlation between the differences of items.

According to the estimation results obtained from the model, while the lagged value of the dependent variable $\left(Z S_{i, t-1}\right)$, DS, BS, DA and LTA have a statistically significant and negative impact on bank risk. ROE and Tier1 have a statistically significant and positive impact on bank risk.

\section{RESULTS AND DISCUSSION}

With the increase in international trade volume, it has become inevitable for countries to be exposed to commodity, foreign currency, financial assets and interest risks. The instruments that allow these risks to be minimized or eliminated are derivative products. Banks, which are an important actor in the financial system, resort to derivative instruments to hedge foreign currency risk. 
The study aimed to investigate the relationship between the derivative positions taken by banks for hedging and bank risk in developing countries. For this purpose, 47 banks operating in Turkey, Malaysia, Egypt, Indonesia, Nigeria and Pakistan, whose data were obtained from D-8 countries, were included in the study. The dependent variable, Z-score; The independent variables consist of a derivative volume and bank-s pecific control variables. System GMM method was used to estimate the model of the study.

According to the findings, the relationship between financial derivatives use and bank risk is statistically significant and negative. This finding indicates that banks can reduce their risks by using derivative instruments. The relationship between deposit/total assets ratio and bank risk is statistically negative and significant. The ratio measures the size of assets financed by deposits. It is considered to have a positive effect on risk in terms of cost reduction as there are cheaper alternatives to the deposit fund. Thus, it has a diminishing effect on bank risk. A negative and statistically significant relationship was found between bank risk and bank size, which means that banks will encounter less risk as their assets increase.

Bank risk and liquidity ratio have a statistically significant and negative relationship. This finding indicates that increasing the liquidity ratio reduces bank risk and may make banks less vulnerable to failure. Moreover, the return on equity has a positive effect on bank risk. The reason for this is that the assumption of the increase in return on equity will raise the expectation of return gained causing an uprising in risk. Capital adequacy was another variable that positively affected bank risk. It is an expected situation that the capital adequacy ratio alone will not have a sufficient effect on the bank risk. Increasing equity is costly. To increase the profitability of the bank, it can act according to the interests of the bank owners by taking more risky loans and this may adversely affect the depositors. Therefore, banks operating with high capital can engage in risky activities.

The study's findings are congruent with those of the results obtained by $\mathrm{Li}$ and $\mathrm{Yu}$ (2010) and Ghosh (2017) on developed countries but in inverse directions. The reason behind this is that derivatives are mostly utilized for speculation in developed countries and hedging in developing countries. This study can be improved in developed and developing country samples, comparatively and based on the derivative instrument type.

Ethics Statement: In this study, no method requiring the permission of the "Ethics Committee" was used.

Author Contributions Statement: 1 st author's contribution rate 60\%, 2nd author's contribution rate $40 \%$.

Conflict of Interest: There is no conflict of interest among the authors.

Etik Beyan: Bu çalı̧̧mada "Etik Kurul” izni alınmasını gerektiren bir yöntem kullanılmamıştır.

Yazar Katkı Beyanı: 1. Yazarın katkı oranı \%60, 2. Yazarın katkı oranı ise \%40'dir.

Çıkar Beyanı: Yazarlar arasında çıkar çatışması yoktur.

\section{REFERENCES}

Adcock, C., Hua, X., Mazouz, K., \& Yin, S. (2014). Derivative activities and Chinese banks' exposures to exchange rate and interest rate movements. The European Journal of Finance, 23(7-9), 727-751. https://doi.org/10.1080/1351847X.2014.899260

Afonso, A., \& Rault, C. (2010). What do we really know about fiscal sustainability in the EU? A panel data diagnostic. Review of World Economics, 145(4), 731-755. https://doi.org/10.1007/s10290$\underline{009-0034-1}$

Ahmed, H., Azevedo, A., \& Guney, Y. (2014). The effect of hedging on firm value and performance: Evidence from the nonfinancial UK firms. European Financial Management 2014 Annual Conference (pp. 1-31). University of Rome Tor Vergata-School of Economics. https://efmaefm.org/0EFMAMEETINGS/EFMA\%20ANNUAL\%20MEETINGS/2014Rome/papers/EFMA2014 0342 fullpaper.pdf 
Arellano, M., \& Bond, S. (1991). Some tests of specification for panel data: Monte Carlo evidence and an application to employment. Review of Economic Studies. 58(2), 277-297. https://doi.org/10.2307/2297968

Baykut, E., Özen, E., \& Yeşildağ, E. (2019). Likiditenin karlılık üzerine etkisi: BİST ticaret endeksi için GMM modeli uygulaması. Finans Ekonomi ve Sosyal Araştırmalar Dergisi, 4(4), 599-608. https://doi.org/10.29106/fesa.662717

Bowsher, C. G. (2002). On testing overidentifying restrictions in dynamic panel data models. Economics letters, 77(2), 211-220. https://doi.org/10.1016/S0165-1765(02)00130-1

Chang, C. C., Ho, K. Y., \& Hsiao, Y. J. (2018). Derivatives usage for banking industry: Evidence from the European markets. Review of Quantitative Finance and Accounting, 51(4), 921-941. https://doi.org/10.1007/s11156-017-0692-3

Field, A. P. (2009). Discovering statistics using SPSS: (And sex, drugs and rock " $n$ " roll) (3rd ed.). SAGE Publications.

Ghosh, A. (2017). How do derivative securities affect bank risk and profitability? Evidence from the US commercial banking industry. The Journal of Risk Finance, 18(2), 186-213. https://doi.org/10.1108/JRF-09-2016-0116

Global from Asia. (2018, April 22). List of top banks in Malaysia. https://www.globalfromasia.com/banks-in-malaysia/

Gujarati, D. N. (2004). Basic econometrics (4. Edition). McGraw Hill Companies.

Gunther, J., \& Siems, T. F. (1995). Who's capitalizing on derivatives?. Financial Industry Studies. July. 1-19. https://ssrn.com/abstract=6876

Hapijournal. (2018, May 10). The best banks in Egypt. https://hapijournal.com/2020/10/02/

Im, K. S., Pesaran, M. H., \& Shin, Y. (2003). Testing for unit roots in heterogeneous panels. Journal of Econometrics, 115(1), 53-74. https://doi.org/10.1016/S0304-4076(03)00092-7

Indonesia Investment. (2018, May 30). What are Indonesia's biggest bank in terms of assets. https://www.indonesia-investments.com/news/todays-headlines/what-are-indonesia-s-biggestbanks-in-terms-of-assets/item8923

İskenderoğlu, Ö. (2008). İşletmelerin büyümesinde büyüklüğ̈̈n etkisi: Türkiye için bir inceleme. Nobel Kitabevi.

Kasilingam, R. (1997). Financial derivatives. Pondicherry University. https://backup.pondiuni.edu.in/sites/default/files/downloads/Financial-derivatives-260214.pdf

KPMG Banking Survey. (2018, March https://assets.kpmg/content/dam/kpmg/pk/pdf/2019/05/Banking\%20Results\%202018\%20\%20.p $\underline{\mathrm{df} /}$

Lenee, T. L., \& Oki, J. (2016). Financial derivatives and firm performance: Empirical evidence from financial and non financial firms. British Journal of Economics, Management and Trade, 16(4). 1-36. https://doi.org/10.9734/BJEMT/2017/30106

Levin, A., Lin, C. F., \& Chu, C. S. J. (2002). Unit root tests in panel data: Asymptotic and finitesample properties. Journal of Econometrics, 108(1), 1-24. https://doi.org/10.1016/S03044076(01)00098-7

Li, L., \& Yu, Z. (2010). The impact of derivatives activity on commercial banks: Evidence from U.S. bank holding companies. Asia-Pacific Financial Markets, 17(3), 303-322. https://doi.org/10.1007/s10690-010-9117-1

Mallikarjunappa, T., \& Afsal, E. M. (2008). The impact of derivatives on stock market volatility: A study of the Nifty Index. Asian Academy of Management Journal of Accounting and Finance, 
4(2),43-65.

https://citeseerx.ist.psu.edu/viewdoc/download?doi=10.1.1.1068.3476\&rep=rep1\&type=pdf

McDonald, L. R. (2013). Derivatives market. Pearson Education.

Morgan, J. P. (2013). Derivatives and risk management made simple. National Association of Pension Funds Limited. https://pdf4pro.com/view/derivatives-and-risk-management-made-simple4d8c49.html

Rivas, A., Ozuna, T., \& Policastro, F. (2006). Does the use of derivatives increase bank efficiency? Evidence from Latin American banks. International Business \& Economics Research Journal, 5(11), 47-56. https://doi.org/10.19030/iber.v5i11.3525

Shen, X., \& Hartarska, V. (2013). Derivatives as risk management and performance of agricultural banks. Agricultural Finance Review, 73(2), 290-309. https://doi.org/10.1108/AFR-07-2012$\underline{0036}$

Start Credits. (2018), The 2019-2018 top banks in Nigeria by assets. https://startcredits.com/the-2019top-banks-in-nigeria-by-assets/

Sundaram, R. K., \& Das, S. R. (2011). Derivatives: Principles and practice. McGraw-Hill Irwin.

The Banks Association of Turkey. (2018). The ranking of Turkish Banks according to assets size. https://www.tbb.org.tr/tr/banka-ve-sektor-

bilgileri/istatistikiraporlar/Aktif Buyukluklerine Gore Banka Siralamasi/3762

Topaloğlu, E. E. (2018). Bankalarda finansal kırılganlı̆̆ etkileyen faktörlerin panel veri analizi ile belirlenmesi. Eskişehir Osmangazi Üniversitesi İktisadi ve İdari Bilimler Dergisi, 13(1), 15-38. https://doi.org/10.17153/oguiibf.344856

Vo, D. H., Huynh, S. V., \& Ha, D. T. T (2019). The importance of the financial derivatives markets to economic development in the world's four major economies. Journal of Risk and Financial Management, 12(1), 1-18. https://doi.org/10.3390/jrfm12010035

Yılmaz, E., \& Arslan, T. (2016). Finansal risklerin yönetilmesinde türev ürünlerin kullanımı: Borsa İstanbul (BIST) 100 Endeksi'ndeki şirketler üzerine bir araştırma. İşletme Araştırmaları Dergisi, 8(1), 663-678. https://doi.org/10.20491/isader.2016.165 